\title{
Acute metabolic response in myocardial infarction
}

\author{
L. H. Opie
}

From the M.R.C. Cardiovascular Research Unit and Department of Medicine, Royal Postgraduate Medical School, Hammersmith Hospital, London W.I2

Acute myocardial infarction is viewed as a severe trauma causing a generalized metabolic reaction; an acute emotional stress with further metabolic implications; and a localized wound in which there is an acute increase in carbohydrate metabolism, followed by protein synthetic reactions leading to scar formation. The metabolic response is vital to the patient's successful adaptation to his myocardial infarction.

Acute myocardial infarction is a traumatic event. It is a trauma to the body as a whole and hence may be expected to call forth a generalized metabolic response. It is a psychological trauma and typically elicits acute anxiety. It is also a trauma to the myocardium, where a complex biochemical response results.

\section{Myocardial infarction as an acute physi- cal stress}

Acute myocardial infarction may be viewed as an example of an acute physical disease state and as such would participate in the hormonal changes found in other medical or surgical diseases. These hormonal changes include increased plasma concentrations of ACTH (Nabarro, 1969) and of cortisol (Jacobs and Nabarro, 1969). There is probably increased secretion of these hormones (Nabarro, I969). In patients with acute burns there are high levels of urinary adrenaline and noradrenaline excretion, correlating with adrenocorticol hormone secretion (Birke et al., I958); other findings include glucose intolerance, a high concentration of circulating free fatty acids, and failure of response of plasma immunoreactive insulin to intravenous glucose (Allison, Hinton, and Chamberlain, I968). Such observations may explain the hyperglycaemia and pseudodiabetes found in acute burned patients (Bailey, 1960). Parallel observations in patients with a variety of physical stresses show that the plasma insulin level does not rise in spite of stress-caused hyperglycaemia (Schalch, 1967). Other changes include increased circulating free thyroxin in the plasma (Anderson, 1968a), but there is a relatively normal value for circulating growth hormone (Jacobs and Nabarro, 1969).

Many of these changes could be explained by supposing that the patient undergoes an acute stress reaction, resulting in a series of hormonal changes. A probable sequence of events may be as follows. Hypothalmic stimulation may lead to ACTH release, adrenal stimulation, and increased cortisol secretion. Sympathetic nervous system stimulation leads to increased secretion of catecholamines, which in turn results in lipid mobilization and an increased circulating free fatty acid concentration (Carlson, I968). Catecholamine secretion may also suppress insulin secretion (Porte et al., 1966). All of these factors probably contribute to the glucose intolerance which can occur.

\section{Myocardial infarction as an acute emo- tional stress}

It seems inevitable that at some stage the patient with acute myocardial infarction should suffer from acute emotional stress in the form of anxiety. Such anxiety may occur initially when the sudden severe chest pain is typically experienced, or later when he is brought into hospital and enters an acute coronary care unit. Anxiety may even be experienced when he is transferred from the coronary care unit to the general medical ward (Klein et al., 1968). And the complications of myocardial infarction may be the setting for the development of an anxiety neurosis, as found in resuscitated patients after cardiac arrest (fournal of the American Medical Association, 1968). 
Acute emotional stress has its own complications, which are similar to those of acute physical stress and include adrenal cortical and medullary stimulation (see Levi, 1969). Increased circulating free fatty acid concentrations appear to reflect catechol-mediated beta-receptor stimulation (Pinter et al., 1967; Baker et al., 1969; Levi, 1969). Increased circulating triglyceride concentrations may follow the increased free fatty acid levels (Levi, 1969). Of particular interest is the magnitude of some of these responses to severe emotional stress. Urinary adrenaline excretion values may reach $30 \mathrm{ng}$./min. (Levi, 1969), which is similar to the peak values of about $30 \mu \mathrm{g}$. per 24 hours in patients severely ill with acute myocardial infarction (Valori, Thomas, and Shillingford, 1967). When Swedish students viewed sexually arousing films the urinary noradrenaline excretion reached values in excess of $50 \mathrm{ng} . / \mathrm{min}$. in some instances (Levi, 1969), which is similar to values found in the less severely ill patients with myocardial infarction (Valori et al., 1967).

\section{Metabolic complications of acute myo- cardial infarction}

The metabolic consequences of acute myocardial infarction include an increased plasma cortisol concentration (Klein and Palmer, 1963; Logan and Murdoch, 1966) which presumably reflects an increased ACTH secretion. There are increased levels of circulating noradrenaline (Gazes, Richardson, and Woods, I959; McDonald et al., 1969) and probably of adrenaline (Gazes et al., 1959). Circulating free fatty acid concentrations are increased (Oliver, Kurien, and Greenwood, 1968) and glucose utilization is impaired (Sowton, 1962). The similarity of these changes to those found in acute medical and psychological stress situations is apparent. This recognition of acute myocardial infarction as a severe generalized stress seems to be recent in origin; myocardial infarction is not included in the very many other acute stress situations discussed by Selye in 1950.

The complications of acute myocardial infarction may lead to further metabolic changes. Acute left ventricular failure may cause severe dyspnoea, which would contribute to the physical and psychological stress. As expected, urinary catecholamine excretion rates in such patients are increased (Valori et al., 1967; Jewitt et al., 1969). If shock develops there is poor tissue perfusion, with the following consequences: (I) increased circulating blood lactate and an increased lactatepyruvate ratio (MacKenzie et al., 1964; Weil and Shubin, 1968), (2) decreased blood $p \mathrm{H}$
(MacKenzie et al., 1964), and (3) poor insulin secretion (Taylor et al., 1969). Such patients tend to have higher output of urinary catecholamines (Valori et al., 1967; Jewitt et al., 1969). It is also probable that shocked patients have a more severe anxiety reaction.

Much discussion has recently centred around the possible toxic role of circulating free fatty acids in acute myocardial infarction (Oliver et al., 1968; Rutenberg, Pamintuan, and Soloff, 1969; Gupta et al., 1969; Nelson, I970), and dog experiments suggest that extremely high levels of free fatty acids may directly predispose to arrhythmias (Kurien, Yates, and Oliver, I969). This is an intriguing possibility, because high circulating free fatty acid levels are susceptible to therapeutic intervention and in some non-shocked patients intravenous glucose may reduce the free fatty acid values towards normal (Gupta et al., I969). An adipose-tissue specific beta-blocking drug would be a useful investigative tool.

However, the actual level of circulating free fatty acid is the end result of a balance of input into the blood from adipose tissue $(\mathrm{Ca}-$ hill and Renold, 1965) and uptake by the tissues. In normal subjects increased circulating free fatty acid concentrations are thought to reflect increased mobilization from adipose tissue rather than alterations in the rate of uptake by the tissues, and a similar situation is thought to occur in acute myocardial infarction (Carlson, 1968; Gupta et al., 1969). Decreased uptake of free fatty acid by peripheral tissues may, however, play a role in shocked patients with poor peripheral perfusion. Fatty acid turnover studies are needed to settle this point. If increased mobilization of free fatty acid occurs, then the factors concerned may include increased catecholamine secretion (Carlson, 1968; Gupta et al., 1969), alterations in insulin secretion (Allison, Chamberlain, and Hinton, I969), and possibly increased corticosteroid production. Growth hormone is difficult to evaluate because of the extreme lability of the circulating value, but the growth hormone concentration in fasting patients with acute myocardial infarction could not be related to the free fatty acid concentration in blood (Gupta et al., 1969). The effects of simple starvation, which may be related to the degree of adiposity (Opie and Walfish, 1963), must also be considered.

Examples of the problem of interpreting the meaning of the blood free fatty acid concentrations are shown in Fig. $I$ and 2 ; there are acute but variable increases of the urinary catecholamine excretion rates in the initial period in two patients with very severe acute myocardial infarction. The levels of 


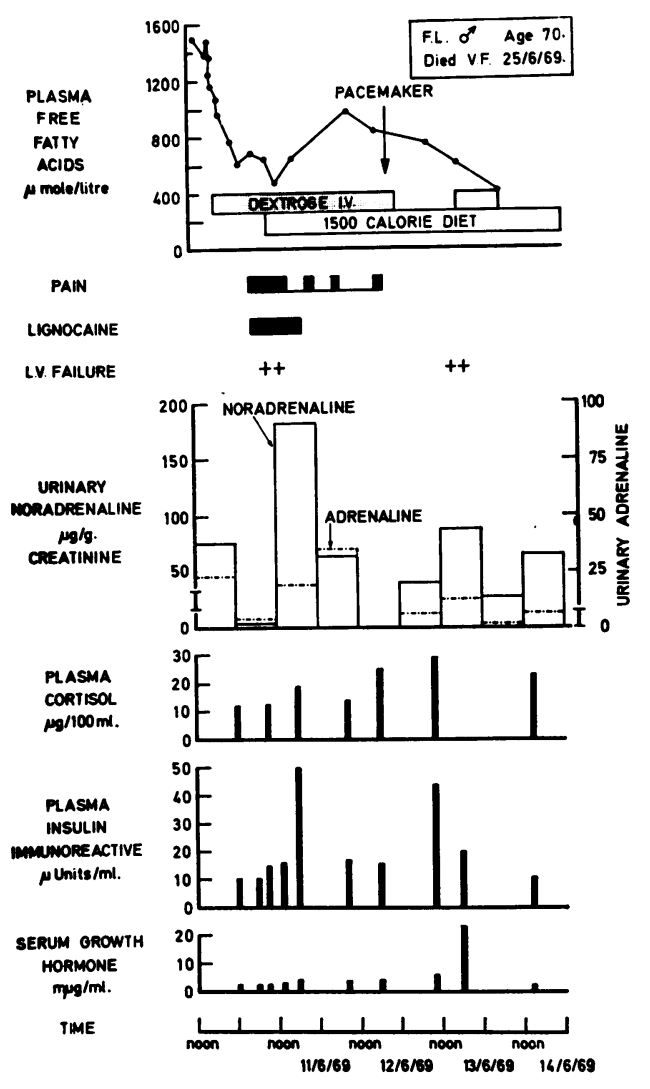

FIG. I Acute metabolic changes in myocardial infarction. Patient admitted two hours after cessation of initial chest pain. Note (I) abrupt decrease in plasma free fatty acid concentration during infusion of dextrose $10 \%$ (500 ml. every eight hours); (2) highest values of free noradrenaline excretion in urine not on admission but during clinical complications (recurrent pain, left ventricular failure, and ectopic activity) on next day. Normal urinary noradrenaline and adrenaline values are indicated by standard error bars on either side; (3) plasma cortisol levels bear no relationship to clinical events; (4) plasma insulin levels do not rise during plasma free fatty acid fall at time of dextrose infusion; and (5) variable growth hormone values. Patient died from ventricular fibrillation fifteen days after admission.

circulating growth hormone, cortisol, and immunoreactive insulin all vary. These factors, together with a changing diet and the administration of drugs such as heparin (Fig. 3) and propranolol, may influence the concentration of circulating free fatty acid. Metabolic variability is not surprising in a condition in which there is constant therapeutic intervention and conditions are inevitably non-basal.

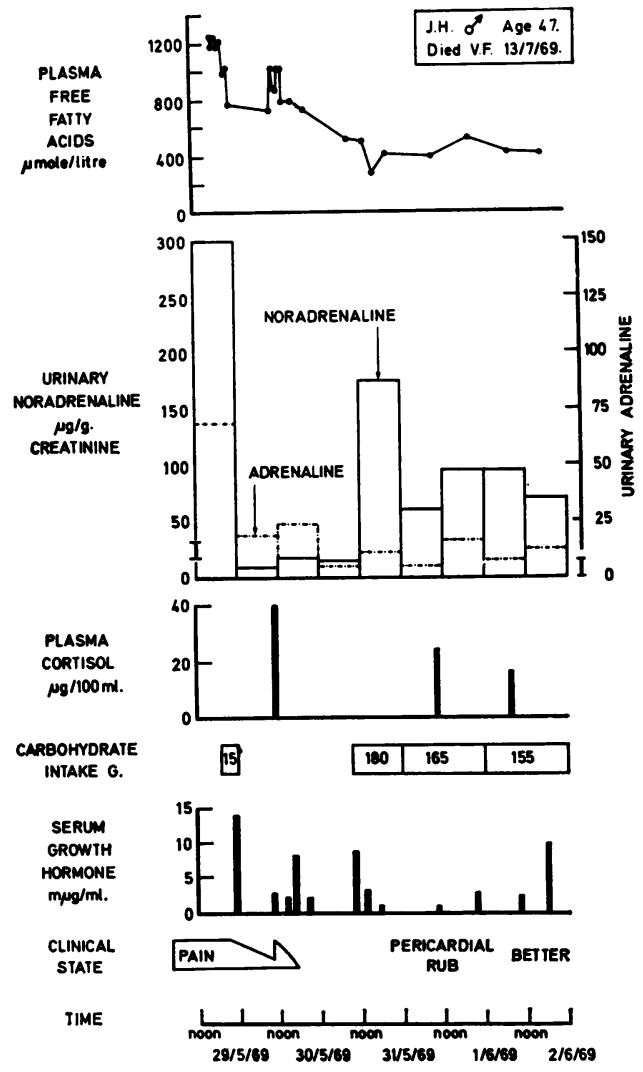

FIG. 2 Acute metabolic changes in myocardial infarction. Note ( $I$ ) abrupt fall of plasma free fatty acid concentration in relation to infusion of dextrose $10 \%$ (indicated by carbohydrate intake of 15 g.), despite very high urinary catecholamine excretion values; (2) subsequent rise of plasma free fatty acid concentration at time of recurrent pain, anxiety, and a very high plasma cortisol value (greater than $40 \mathrm{\mu g}$./100 ml.); however, urinary catecholamine excretion values were falling towards normal (indicated by standard error bars at either side); (3) variable growth hormone values; and (4) failure of plasma free fatty acid concentration to mirror urinary catecholamine excretion values during episode of pericarditis at a time when carbohydrate intake was adequate.

It is both difficult to assess the significance of the free fatty acid concentration and to be sure that clinical events such as the development of severe arrhythmias are caused by high circulating fatty acid concentrations rather than by the associated changes in production rates of hormones such as catecholamines. Nevertheless, the high concentration of free fatty acid in the blood is abnormal, 
EFFECT OF HEPARIN 10,000 UNITS IV. MUECTION ON PLASEMA FREE FATTY ACIOS

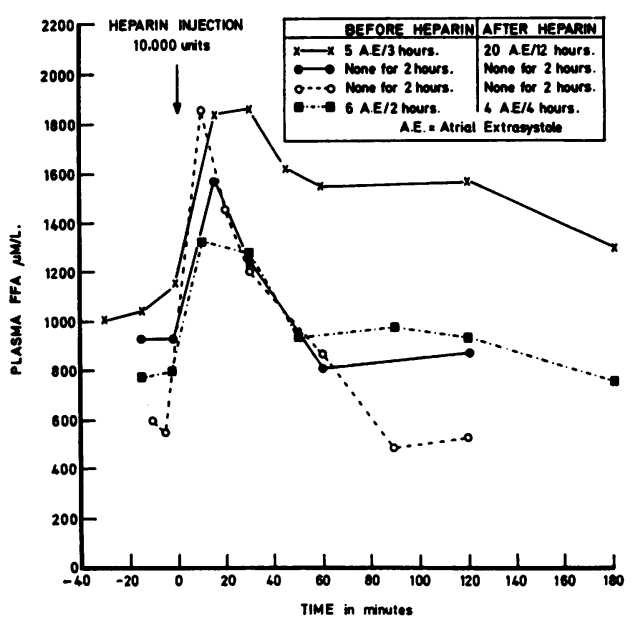

FIG. 3 Effects of heparin injection on plasma free fatty acid concentrations in acute myocardial infarction. The patients were not studied under standardized conditions. Note rise of free fatty acid values without development of arrhythmias. The heart rhythm was continuously monitored for the times indicated. Also see Nelson (1970).

as is the decreased glucose utilization. An increased glucose utilization may benefit the ischaemic myocardium by increased anaerobic energy production (Brachfeld and Scheuer, 1967), although this effect can only be of very marginal benefit from the point of view of the energy required by normally contracting cardiac tissue (Opie, 1970a). Increased glucose transport into oxygen-deficient cells may help to maintain the membrane action potential (MacLeod and Daniel, 1965). Increased circulating glucose concentrations may benefit the ischaemic myocardium by an osmotic effect which reduces the amount of potassium loss (Burke et al., 1969), and also by lowering the circulating free fatty acid concentration (Gupta et al., 1969). The latter effect may well vary according to the major cause of the high fatty acid values in a given patient (Porte et al., I966). Very high concentrations of circulating free fatty acids may be toxic to the ischaemic (Kurien et al., 1969) or to the hypoxic heart (Henderson et al., 1970), and even to the normal isolated perfused heart in certain circumstances (Opie, 1970b). It still remains to be shown that the blood free fatty acid levels found in patients with acute myocardial infarction are toxic to the heart.

In the patients shown in Fig. I and 2, the abrupt decreases in the circulating free fatty acid concentrations in the early stages were apparently related to the intravenous administration of glucose; there were simultaneous rises in the circulating blood glucose concentrations. Subsequently, while these patients were on a light 1500 -calorie diet, the circulating free fatty acid concentrations were never very high in spite of clinical complications and high urinary catecholamine excretion rates.

The traditional policy of starving patients with acute myocardial infarction in the initial stages may not be correct. We now accept that patients with acute surgical stress recover sooner if the acute metabolic changes are corrected by intravenous therapy if needed, and there are arguments for exploring a similar policy in acute myocardial infarction.

\section{The localized metabolic response}

To study the local metabolic response requires direct access to the myocardium or to blood draining the ischaemic area. Hence, virtually all studies on local changes in myocardial infarction have been on experimental animals, in which it is nearly impossible to duplicate the complex generalized hormonal-metabolic response found in patients with acute myocardial infarction. Studies on anaesthetized animals, frequently using open-chest procedures, have usually assumed that the basic event in patient acute myocardial infarction is total coronary occlusion; this supposition is seriously questioned by those who feel that the combined effects of severe stress and excess secretion of catecholamines and of corticosteroids may cause infarction in the absence of arterial occlusion (Rona, Kahn, and Chappel, 1963; Raab, 1969).

It is sobering to recall that many of the important metabolic changes in experimental myocardial infarction have been known for over thirty years. There is rapid glycogen breakdown in the ischaemic area with associated release of lactate (Tennant et al., 1936; Bronson, 1938) and hydrogen ion (Moore and Greenberg, 1937). There is loss of the potassium ion (Dennis and Moore, 1938) and gain of oedema fluid (Herrmann and Decherd, 1935). Decreased contractility in the ischaemic area was shown by an optical myographic method in 1935 (Tennant and Wiggers, 1935). The cause of decreased contractility was thought to be lactic acid accumulation with a fall of the intracellular $p \mathrm{H}$ (Katz and Long, 1925; Tennant, 1935). This suggestion has been recently revived in much more sophisticated terms (Katz, I968) according to which the intracellular hydrogen ion accumulation 
displaces the calcium ion from the binding sites on the contractile proteins.

Salient to the localized metabolic response to total arterial occlusion is the concept that the ischaemic tissue suffers from lack of oxygen. It is not known quite how severe the hypoxia is. Studies with tissue oxygen electrodes have suggested that the $\mathrm{Po}_{2}$ in the centre of the ischaemic tissue may drop towards zero within seconds of occlusion (Sayen et al., 1958). Perhaps a severe initial oxygen lack very rapidly breaks down some of the tissue adenosine triphosphate (ATP); its degradation product, adenosine, accumulates only fifteen seconds after coronary occlusion (Olsson, 1970) and is thought to act as a local vasodilator on the coronary circulation (Berne, 1963). Thus ATP breakdown (Lamprecht, I963; Braasch et al., I968) may initiate compensatory vasodilatation and help open the collateral circulation. Since 60 to 70 per cent (or more) of the heart's energy is used for contraction (Opie, 1969), the collateral blood supply, which is about one-third of the control value for some hours (Rees and Redding, 1968; Grayson and Irvine, 1968), should bring sufficient oxygen to the ischaemic area to maintain viability provided that contraction has ceased. Nevertheless, as is well known, parts of the ischaemic area undergo infarction (Jennings, 1969), and the factors operating may include ( $\mathrm{I}$ ) unequal tissue perfusion from the collateral circulation, with severe hypoxia or anoxia in some areas; (2) a decreased rate of collateral flow; (3) continued contraction of parts of the ischaemic area; (4) the severity of the initial loss of ATP and phosphocreatine, which may result in a series of events including continuing potassium loss (Jennings, Kaltenbach, and Sommers, 1965), which could occur even in the presence of oxygen; and (5) release of catecholamines from storage sites in the myocardium, because catecholamines may cause uncoupling of oxidative phosphorylation (Sobel et al., I966) with continued oxidative metabolism but without adequate production of ATP and phosphocreatine.

The substrate metabolism is also affected by coronary artery occlusion. There is an increased usage of glucose relative to that of free fatty acid (Owen, Thomas, and Opie, 1969; Owen et al., 1970). Although free fatty acid is normally an important fuel for the heart, utilization of this substrate is impaired by oxygen lack (Scheuer, 1967). Glycolysis in the ischaemic myocardium is not subject to external control by a high concentration of circulating free fatty acids (Fig. 4), which shows that acute arterial occlusion activates glycolysis sufficiently to overcome the normal in-

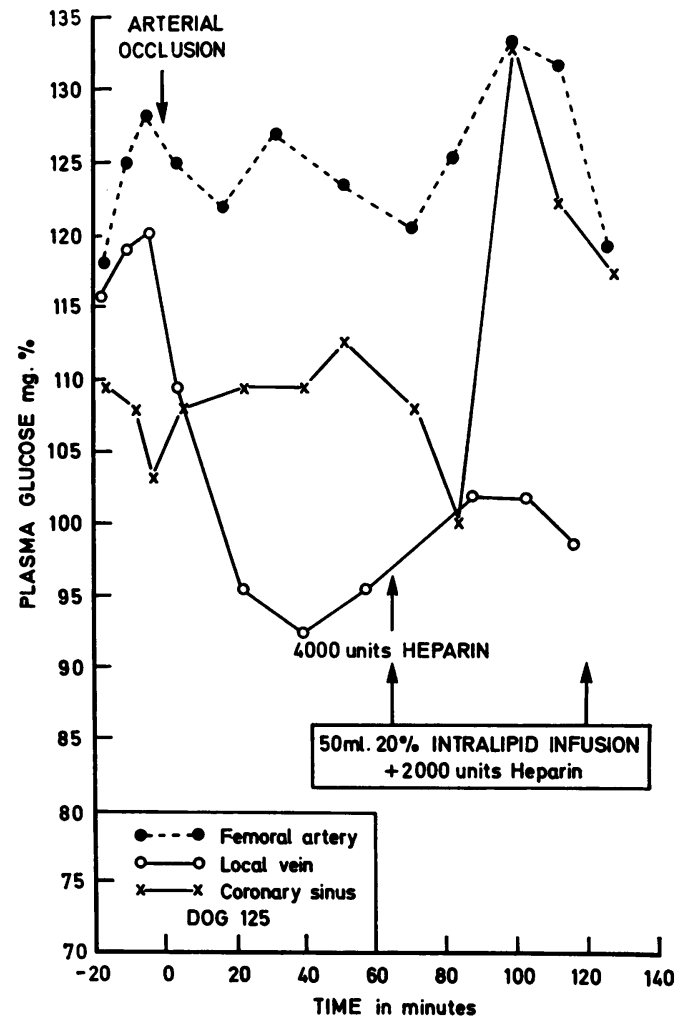

FIG. 4 Experimental myocardial infarction. Local venous blood drains the ischaemic area, and coronary sinus blood the non-ischaemic area (Owen et al., 1970). After coronary artery ligation, arterial-local venous glucose differences increased but arterial-coronary sinus differences were unchanged. When plasma free fatty acid concentrations were increased by an infusion of Intralipid and heparin for the period between arrows, there was failure of the high plasma free fatty acid concentrations (above 4000 umole/l. at end of infusion) to inhibit glucose uptake by the ischaemic area in contrast to inhibition in normal areas.

hibition by fatty acids (Randle et al., I963).

Factors operating to increase carbohydrate metabolism in the ischaemic myocardium may include the effects of hypoxia (Brachfeld, 1969) in stimulating the transport of glucose into the heart cell, breakdown of glycogen, and increased flow through glycolysis. The cellular mechanisms responsible for these changes appear to include (I) the effects of a decreased concentration of adenosine triphosphate (ATP), and an increased concentration of its breakdown products, such as adenosine monophosphate (AMP) and inorganic phosphate (Regen et al., 1964); and 
(2) the activating effects of endogenous catecholamines (Wollenberger, Krause, and Shahab, 1967; Wollenberger and Krause, 1968), which may act by production of cyclic-AMP from ATP (Sutherland, Robison, and Butcher, I968).

\section{Metabolic aspects of arrhythmias}

In such a complex setting, with a constantly changing metabolic situation within and without the ischaemic cells, it is difficult to separate one metabolic event clearly as the sole cause of the genesis of severe arrhythmias. A cautious view at present would be that very sick patients, who are more liable to develop arrhythmias (Jewitt et al., I969; Gupta et al., 1969), are also those more likely to develop severe metabolic complications such as high values of catecholamine excretion, more severe potassium loss, higher circulating free fatty acid concentrations, and a detectable systemic acidosis. In experimental situations each of these factors may contribute to the development of severe arrhythmias.

Using a continuous bioassay technique, Ceremużyński, Staszewska-Barczak, and Herbaczyńska-Cedro (I969) showed that the incidence of ventricular arrhythmias soon after coronary artery ligation was related to the concentration of circulating catecholamine, especially adrenaline. In dogs with complete chronic cardiac denervation the incidence of ventricular arrhythmias was much reduced (Ebert et al., 1970). However, catecholamines may not act directly but via the potassium ion. In the normally oygenated perfused dog heart there is potassium gain after catecholamine administration, but in the ischaemic heart there is potassium loss rather than uptake (Gerlings, Miller, and Gilmore, r969). Arrhythmias in the chronically denervated heart can be provoked by the administration of octylamine, a potassium-releasing depolarizing agent (Vanderbeek and Ebert, 1970). Another suggestion is that catecholamines might act by increasing the intracellular free fatty acid concentration, for example by stimulating the breakdown of triglycerides of the heart (Kurien and Oliver, 1970).

Potassium loss has been linked to arrhythmias in experimental myocardial ischaemia by Harris and colleagues (1954), who found a high coronary venous potassium concentration in association with ventricular fibrillation. Potassium injections also provoked ectopic activity (Harris, Toth, and Hoey, 1958). Regan and co-workers (1967) carried these observations further by showing reversal of both potassium loss and arrhythmias during antiarrhythmic therapeutic intervention such as procain amide. However, in other dog experiments, the antiarrhythmic agents lignocaine, procain amide, and propranolol were effective without reversing potassium loss (Thomas et al., 1970).

In considering the posulated toxic effects of free fatty acids (Kurien and Oliver, 1970) the basic biochemical differences between red and white muscle must be considered. White muscle has a lower capacity to metabolize fatty acids than does red. In the heart, the conduction system metabolically resembles white muscle, while the rest of the myocardium closely resembles red muscle (Opie, 1969). The conduction system would therefore be less able to use free fatty acids for oxidative metabolism and might be more prone to accumulate fatty acids. This difference may explain the greater susceptibility of the conduction tissue to the effects of extremely high free fatty acid concentrations.

While it is not thought that a decreased blood $p \mathrm{H}$ by itself causes serious arrhythmias, arterial acidosis predisposes to arrhythmias (Gerst, Fleming, and Malm, 1966), and the correction of acidosis is important in the management of cardiac arrest (Stewart, 1964; Cohen and Uhley, 1966). However, after coronary artery ligation in the dog heart the fall in local venous $p H$ in the blood draining the ischaemic zone was no different in hearts which developed ventricular fibrillation than in hearts which did not (Samson et al., 1970). Clinical evidence favours the suggestion that metabolic acidosis occurring with an arrhythmia is probably the result of circulatory failure rather than the cause of the arrhythmias (Anderson, 1968b).

There is no firm evidence to implicate any single metabolic factor in the genesis of every arrhythmia, but it would be surprising if catecholamines, potassium loss, acidosis, and very high free fatty acid concentrations did not, singly or together, play a part.

\section{End results of local metabolic response}

Quite at what stage the ischaemic cell irreversibly dies has not yet been settled. Probably there is no definite biochemical event which marks the transition from life to death, but rather it is the sum total of a whole sequence of changes which is responsible. Once there is a focus of non-viable cells, then the pathologist can recognize this as infarcted tissue. Although it is infarcted it is not metabolically dead.

The elegant studies of Bing and co-workers (Gudbjarnason et al., 1964) have shown that the heart reacts like other tissues to a wound; 
wound healing is subject to the influence of various hormones, such as insulin and anabolic steroids (Gudbjarnason et al., 1966). Protein synthesis is responsible for the formation of the scar tissue; when once the period of intense protein synthesis is completed the relatively inert residual scar remains. It is this scar which represents the end product of the acute metabolic reaction, and allows the clinician to reassure the patient that the wound on the heart is now healed.

In summary, the acute local metabolic response consists in an abrupt loss of ATP and phosphocreatine which is thought to be responsible for the activation of glycolysis and the shift from lipid to carbohydrate metabolism. Formation of adenosine from ATP may help open the collateral circulation, which could theoretically supply enough oxygen for the noncontracting ischaemic heart. In spite of this compensatory mechanism, cell death may ensue in a proportion of cells. This does not mean cessation of metabolic activity, because there is intense synthesis of protein and wound healing, which results in scar formation.

Professor J. P. Shillingford is thanked for encouragement and support. Much is owed to Dr. Michael Thomas for co-operative studies and valuable criticism and advice. Dr. Rodney Young and Dr. D. Gupta actively collaborated on the studies shown in Fig. I and 2. Miss Patricia Owen and Miss Marion Evans gave excellent assistance. Dr. Roland Samson kindly provided the data in Fig. 3. Dr. Martin Hartog and Dr. David Wright are thanked for assays of growth hormone and insulin, and Dr. Chris Burke for cortisol assays.

\section{References}

Allison, S. P., Chamberlain, M. J., and Hinton, P. (1969). Intravenous glucose tolerance, insulin, glucose, and free fatty acid levels after myocardial infarction. British Medical fournal, 4, 776.

- Hinton, P., and Chamberlain, M. J. (1968). Intravenous glucose-tolerance, insulin, and freefatty-acid levels in burned patients. Lancet, 2 , I 113.

Anderson, B. G. (1968a). Free thyroxine in serum in relation to thyroid function. Fournal of the American Medical Association, 203, 577.

Anderson, R. (1968b). The relation between metabelic acidosis and cardiac arrhythmias in acute myocardial infarction. American Heart fournal, 76, I.

Bailey, B. N. (1960). Hyperglycaemia in burns. British Medical fournal, 2, 1783.

Baker, L., Barcai, A., Kaye, R., and Haque, N. (1969). Beta adrenergic blockade and juvenile diabetes. fournal of Pediatrics, 75, 19.

Berne, R. M. (1963). Cardiac nucleotides in hypoxia: possible role in regulation of coronary blood flow. American fournal of Physiology, 204, 317.

Birke, G., Dunér, H., Liljedahl, S. O., Pernow, B., Plantin, L. O., and Troell, L. (1958). Histamine, catechol amines and adrenocortical steroids in burns. Acta Chirurgica Scandinavica, 114, 87.
Braasch, W., Gudbjarnason, S., Puri, P. S., Ravens, K. G., and Bing, R. J. (I968). Early changes in energy metabolism in the myocardium following acute coronary artery occlusion in anesthetized dogs. Circulation Research, 23, 429.

Brachfeld, N. (1969). Maintenance of cell viability. Circulation, 40, Suppl. 4, 202.

- , and Scheuer, J. (1967). Metabolism of glucose by the ischemic dog heart. American fournal of Physiology, 212, 603 .

Bronson, L. H. (1938). Anatomical and chemical changes in the myocardium following short-term coronary artery occlusion in dogs. Yale fournal of Biology and Medicine, 10, 405.

Burke, W. M., Asokan, S. K., Moschos, C. B., Oldewurtel, H. A., and Regan, T. J. (1969). Effects of glucose and nonglucose infusions on myocardial potassium ion transfers and arrhythmias during ischemia. American fournal of Cardiology, 24, 713 .

Cahill, G. F., Jr., and Renold, A. E. (1965). Regulation of adipose tissue metabolism within the intact organism. In Handbook of Physiology, Adipose Tissue, Section 5, p. 681. Ed. by A. E. Renold and G. F. Cahill, Jr. American Physiological Society, Washington, D.C.

Carlson, L. A. (I968). Fatty acid response to trauma. In Acute Myocardial Infarction, p. 243. Ed. by D. G. Julian and M. F. Oliver. Livingstone, Edinburgh.

Ceremuźyński, L., Staszewska-Barczak, J., and Herbaczyńska-Cedro, K. (1969). Cardiac rhythm disturbances and the release of catecholamines after acute coronary occlusion in dogs. Cardiovascular Research, 3, 190.

Cohen, R. A., and Uhley, H. N. (1966). Monitoring the blood $\mathrm{pH}$ in acute myocardial infarction: the role of acidosis in arrhythmias. Fournal of the American Medical Association, 198, 947.

Dennis, J., and Moore, R. M. (1938). Potassium changes in the functioning heart under conditions of ischemia and of congestion. American fournal of Physiology, 123, 443.

Ebert, P. A., Vanderbeek, R. B., Allgood, R. J., and Sabiston, D. C., Jr. (I970). Effect of chronic cardiac denervation on arrhythmias after coronary artery ligation. Cardiovascular Research, 4, I4I.

Gazes, P. C., Richardson, J. A., and Woods, E. F. (I959). Plasma catechol amine concentrations in myocardial infarction and angina pectoris. Circulation, 19, 657 .

Gerlings, E. D., Miller, D. T., and Gilmore, J. P. (1969). Oxygen availability: a determinant of myocardial potassium balance. American fournal of Physiology, 216, 559.

Gerst, P. H., Fleming, W. H., and Malm, J. R. (1966). A quantitive evaluation of the effects of acidosis and alkalosis upon the ventricular fibrillation threshold. Surgery, 59, ro5o.

Grayson, J., and Irvine, M. (1968). Myocardial infarction in the monkey; studies on the collateral circulation after acute coronary occlusion. Cardiovascular Research, 2, 170.

Gudbjarnason, S., De Schryver, C., Chiba, C., Yamanaka, J., and Bing, R. J. (1964). Protein and nucleic acid synthesis during the reparative processes following myocardial infarction. Circulation Research, 15, 320.

—, Fenton, J. C., Wolf, P. L., and Bing, R. J. (I966). Stimulation of reparative processes following experimental myocardial infarction. Archives of Internal Medicine, 118, 33. 
Gupta, D. K., Young, R., Jewitt, D. E., Hartog, M., and Opie, L. H. (1969). Increased plasma-freefatty-acid concentrations and their significance in patients with acute myocardial infarction. Lancet, 2, 1209.

—, Bisteni, A., Russell, R. A., Brigham, J. C., and Firestone, J. E. (1954). Excitatory factors in ventricular tachycardia resulting from myocardial ischemia: potassium a major excitant. Science, 119, 200.

Harris, A. S., Toth, L. A., and Hoey, T. E. (1958). Arrhythmic and antiarrhythmic effects of sodium, potassium, and calcium salts and of glucose injected into coronary arteries of infarcted and normal hearts. Circulation Research, 6, 570.

Henderson, A. H., Most, A. S., Parmley, W. W., Gorlin, R., and Sonnenblick, E. H. (I970). Depression of myocardial contractility in rats by free fatty acids during hypoxia. Circulation Research, 26, 439.

Herrmann, G., and Decherd, G. (1935). Creatine and glycogen content of normal and infarcted heart muscle of the dog. Proceedings of the Society for Experimental Biology and Medicine, 32, 1304.

Jacobs, H. S., and Nabarro, J. D. N. (1969). Plasma II-hydroxycorticosteroid and growth hormone levels in acute medical illnesses. British Medical fournal, 2, 595.

Jennings, R. B. (1969). Early phase of myocardial ischemic injury and infarction. American fournal of Cardiology, 24, 753.

—, Kaltenbach, J. P., and Sommers, H. M. (1965). Cell death: electrolyte alterations in injured and dying myocardial cells. In Electrolytes and Cardiovascular Diseases, p. 192. Ed. by E. Bajusz. Karger, Basle; Williams and Wilkins, Baltimore.

Jewitt, D. E., Mercer, C. J., Reid, D., Valori, C., Thomas, M., and Shillingford, J. P. (1969). Free noradrenaline and adrenaline excretion in relation to the development of cardiac arrhythmias and heart-failure in patients with acute myocardial infarction. Lancet, $1,635$.

fournal of the American Medical Association (1968). Editorial. New background for neurosis. 205, 697.

Katz, A. M. (1968). Effects of interrupted coronary flow upon myocardial metabolism and contractility. Progress in Cardiovascular Disease, ro, 450.

Katz, L. N., and Long, C. N. H. (1925). Lactic acid in mammalian cardiac muscle. I. The stimulation maximum. Proceedings of the Royal Society. Series $B$. Biological Sciences, 99, 8.

Klein, A. J., and Palmer, L. A. (1963). Plasma cortisol in myocardial infarction. A correlation with shock and survival. American fournal of Cardiology, Ir, 332.

Klein, R. F., Troyer, W. G., Thompson, H. K., Bogdonoff, M. D., and Wallace, A. G. (I968). Catecholamine excretion in myocardial infarction. Archives of Internal Medicine, 122, 476.

Kurien, V. A., and Oliver, M. F. (1970). A metabolic cause for arrhythmias during acute myocardial hypoxia. Lancet, 1, 813.

$\longrightarrow$, Yates, P. A., and Oliver, M. F. (1969). Free fatty acids, heparin, and arrhythmias during experimental myocardial infarction. Lancet, $2,185$.

Lamprecht, W. (1963). The effect of acute and chronic ischemia on myocardial contractility. In The Etiology of Myocardial Infarction (Henry Ford Hospital International Symposium), p. 393 . Ed. by T. N. James and J. W. Keyes. Little, Brown, Boston; Churchill, London.
Levi, L. (1969). Neuro-endocrinology of anxiety. In Studies of Anxiety (British Journal of Psychiatry, Special Publication No. 3), p. 40. Ed. by M. H. Lader.'Headley, London.

Logan, R. W., and Murdoch, W. R. (1966). Bloodlevels of hydrocortisone, transaminases, and cholesterol after myocardial infarction. Lancet, 2, 521 .

McDonald, L., Baker, C., Bray, C., McDonald, A., and Restieux, N. (1969). Plasma-catecholamines after cardiac infarction. Lancet, 2, I02I.

MacKenzie, G. J., Taylor, S. H., Flenley, D. C., McDonald, A. H., Staunton, H. P., and Donald, K. W. (1964). Circulatory and respiratory studies in myocardial infarction and cardiogenic shock. Lancet, 2, 825.

MacLeod, D. P., and Daniel, E. E. (1965). Influence of glucose on the transmembrane action potential of anoxic papillary muscle. Fournal of General Physiology, 48, 887 .

Moore, R. M., and Greenberg, M. M. (1937). Acid production in the functioning heart under conditions of ischemia and of congestion. American fournal of Physiology, 118, 217.

Nabarro, J. D. N. (1969). The metabolic and endocrine response to acute medical stress. Proceedings of the Royal Society of Medicine, 62, 351.

Nelson, P. G. (1970). Effect of heparin on serum freefatty-acids, plasma catecholamines, and the incidence of arrhythmias following acute myocardial infarction. British Medical fournal, 2, 735.

Oliver, M. F., Kurien, V. A., and Greenwood, T. W. (1968). Relation between serum-free-fatty-acids and arrhythmias and death after acute myocardial infarction. Lancet, 1, 7 IO.

Olsson, R. A. (1970). Changes in content of purine nucleoside in canine myocardium during coronary occlusion. Circulation Research, 26, 301.

Opie, L. H. (1969). Metabolism of the heart in health and disease. Part II. American Heart fournal, 77, 100. -(1970a). The glucose hypothesis: Relation to acute myocardial ischaemia. Fournal of Molecular and Cellular Cardiology, r, 107.

- (1970b). Effect of fatty acids on contractility and rhythm of the heart. Nature (London), 227, 1055.

- , and Walfish, P. G. (1963). Plasma free fatty acid concentrations in obesity. New England fournal of Medicine, 268, 757.

Owen, P., Thomas, M., and Opie, L. (1969). Relative changes in free-fatty-acid and glucose utilisation by ischaemic myocardium after coronary-artery occlusion. Lancet, I, I187.

,$- \ldots$, Young, V., and Opie, L. (1970). Comparison between metabolic changes in local venous and coronary sinus blood after acute experimental coronary arterial occlusion. American fournal of Cardiology, 25, 562.

Pinter, E. J., Peterfy, G., Cleghorn, J. M., and Pattee, C. J. (1967). The influence of emotional stress on fat mobilization: the role of endogenous catecholamines in the $\beta$ adrenergic receptors. American fournal of the Medical Sciences, 254, 634.

Porte, D., Jr., Graber, A. L., Kuzuya, T., and Williams, R. H. (I966). The effect of epinephrine on the immunoreactive insulin levels in man. fournal of Clinical Investigation, 45, 228.

Raab, W. (1969). Myocardial electrolyte derangement: crucial feature of pluricausal, so-called coronary heart disease. Annals of the New York Academy of Sciences, 147, 627.

Randle, P. J., Garland, P. B., Hales, C. N., and Newsholme, E. A. (1963). The glucose fatty-acid cycle. Its role in insulin sensitivity and the metabolic disturbances of diabetes mellitus. Lancet, 1,785 . 
Rees, J. R., and Redding, V. J. (1968). Experimental myocardial infarction by a wedge method: early changes in collateral flow. Cardiovascular Research, 2, 43 .

Regan, T. J., Harman, M. A., Lehan, P. H., Burke, W. M., and Oldewurtel, H. A. (1967). Ventricular arrhythmias and $\mathrm{K}^{+}$transfer during myocardial ischemia and intervention with procaine amide, insulin, or glucose solution. Fournal of Clinical Investigation, 46, 1657.

Regen, D. M., Davis, W. W., Morgan, H. E., and Park, C. R. (1964). The regulation of hexokinase and phosphofructokinase activity in heart muscle. Effects of alloxan diabetes, growth hormone, cortisol, and anoxia. Fournal of Biological Chemistry, 239, 43.

Rona, G., Kahn, D. S., and Chappel, C. I. (I963). Studies on infarct-like myocardial necrosis produced by isoproterenol: a review. Review of Canadian Biology, 22, 241.

Rutenberg, H. L., Pamintuan, J. C., and Soloff, L. A. (1969). Serum-free-fatty acids and their relation to complications after acute myocardial infarction. Lancet, 2, 559.

Samson, R., Owen, P., Thomas, M., and Opie, L. H. (1970). Effect of acute experimental coronary artery ligation on local coronary venous blood $\mathrm{pH}$ and $\mathrm{Po}_{2}$. In preparation.

Sayen, J. J., Sheldon, W. F., Peirce, G., and Kuo, P. T. (1958). Polarographic oxygen, the epicardial electrocardiogram and muscle contraction in experimental and acute regional ischemia of the left ventricle. Circulation Research, 6, 779.

Schalch, D. S. (1967). The influence of physical stress and exercise on growth hormone and insulin secretion in man. fournal of Laboratory and Clinical Medicine, 69, 256.

Scheuer, J. (1967). Myocardial metabolism in cardiac hypoxia. American Fournal of Cardiology, 19, 385.

Selye, H. (1950). The Physiology and Pathology of Exposure to Stress. Acta Inc., Montreal.

Sobel, B., Jequier, E., Sjoerdsma, A., and Lovenberg, W. (1966). Effect of catecholamines and adrenergic blocking agents on oxidative phosphorylation in rat heart mitochondria. Circulation Research, 19, I050.

Sowton, E. (1962). Cardiac infarction and the glucosetolerance test. British Medical fournal, $\mathbf{1}, 84$.
Stewart, J. S. S. (1964). Management of cardiac arrest, with special reference to metabolic acidosis. British Medical fournal, r, 476.

Sutherland, E. W., Robison, G. A., and Butcher, R. W. (1968). Some aspects of the biological role of adenosine-3',5'-monophosphate. Circulation, 37, 279.

Taylor, S. H., Saxton, C., Majid, P. A., Dykes, J. R. W., Ghosh, P., and Stoker, J. B. (1969). Insulin secretion following myocardial infarction. Lancet, 2, 1373.

Tennant, R. (1935). Factors concerned in the arrest of contraction in an ischemic myocardial area. American fournal of Physiology, $113,677$.

-, Grayzel, D. M., Sutherland, F. A., and Stringer, S. W. (1936). Studies on experimental coronary occlusion: chemical and anatomical changes in the myocardium after coronary ligation. American Heart fournal, 12, 168.

—, and Wiggers, C. J. (1935). The effect of coronary occlusion on myocardial contraction. American fournal of Physiology, 112, 35I.

Thomas, M., Opie, L. H., Katz, R., Shulman, G., and Owen, P. (1970a). Dissociation between potassium loss and antiarrhythmic effect of various drugs after acute experimental coronary artery ligation. In preparation.

Valori, C., Thomas, M., and Shillingford, J. (I967). Free noradrenaline and adrenaline excretion in relation to clinical syndromes following myocardial infarction. American fournal of Cardiology, 20, 605.

Vanderbeek, R. B., and Ebert, P. A. (1970). Potassium release in denervated heart. American fournal of Physiology, 218, 803.

Weil, M. H., and Shubin, H. (1968). Shock following acute myocardial infarction: current understanding of hemodynamic mechanisms. Progress in Cardiovascular Disease, II, I.

Wollenberger, A., and Krause, E. G. (1968). Metabolic control characteristics of the acutely ischemic myocardium. American fournal of Cardiology, 22, 349. - - - and Shahab, L. (1967). Endogenous catecholamine mobilization and the shift to anaerobic energy production in the acutely ischemic myocardium. In (International Symposium) Coronary Circulation and Energetics of the Myocardium, Milan, 1966, p. 200. Ed. by G. Marchetti and B. Taccardi. Karger, Basle and New York. 